\title{
Organic Synthesis and Biological Signal Transduction
}

\author{
Thierry Schmittberger, Herbert Waldmann*
}

Institut für Organische Chemie, Universität Karlsruhe, Richard-Willstätter-Allee 2, D-76128 Karlsruhe, Germany

Fax: +49 721-608-4825, E-mail: waldmann@ochhades.chemie.uni-karlsruhe.de

Received 24 February 1998

\begin{abstract}
Today, many biological phenomena are being both investigated and understood in molecular detail, and organic chemistry is increasingly being directed towards biological phenomena. Thus, the field of "bioorganic chemistry", which encompasses both biological and chemical research, has developed at the border between these two disciplines. The interplay of organic chemistry and biology will be illustrated in this review, using biological signal transduction as an example.
\end{abstract}

1. Introduction

2. Biological signal transduction

3. Inhibition of protein tyrosine kinases (PTKs)

4. Inhibition of the Ras farnesyl transferase (PFTase)

5. Peptide conjugates as tools for study of biological signal transduction

\section{Introduction}

Biological phenomena are based on chemical transformations and depend on the structure and interactions of the molecules involved. In principle, all biological processes can be reduced to chemical ones: biology is molecular. ${ }^{[1]}$ Today, many biological phenomena (such as biological signal transduction) are being both investigated and understood in molecular detail, and the increasingly important field of structural biology is becoming more prominent on the horizon of organic chemistry. ${ }^{[2]}$ Due to the high performance of organic synthesis today even the most complicated of those natural and active compounds which are recognized as biologically relevant can be synthesized; noncovalent interactions between large natural molecules that determine processes such as protein-protein and protein-DNA interactions, and recognition phenomena at cell surfaces, are the focus of "supramolecular chemistry". As the kinds and dimensions of the subjects of biological and organic chemical research have become more similar, these sciences have begun to permeate one another, and at their interface, a growing interdisciplinary field has been established: bioorganic chemistry.

In this review, the successful interlocking of biological and organic chemical research, will be presented using "biological signal transduction" as an example of current relevance. ${ }^{[3]}$

\section{Biological signal transduction ${ }^{[4,5]}$}

For multicellular organisms to maintain functional and survival capacity, the growth, differentiation, and metabolism of a large number of cells must be coordinated via synthesis, secretion and recognition of signal molecules, sometimes over relatively large distances. Once the signal has been conveyed through the plasma membrane of the target cell, the message is relayed into the cell interior via intracellular signal cascades, and a reaction is triggered. According to their physical characteristics, extracellular signal substances (hormones) are recognized by receptors in the cell interior (lipophilic hormones such as steroids and thyroid hormone) or they are bound to receptors on the cell surface (hydrophilic hormones such as peptide hormones). Finally, the signal is switched off and the reaction of the cell to the signal substance ends. The activity of the latter class of hormones and associated signal mediation has been the subject of particularly intensive bio-organic research. In the following section, the Ras signal cascade is outlined as an example of the most important intracellular signal cascades relevant to this class of hormones.

\subsection{Signal transduction via receptor-tyrosine kinases and non- receptor-tyrosine kinases - the Ras/MAP kinase signal transduction cascade ${ }^{[5,6-14]}$}

Many of the polypeptide hormones influencing cell proliferation and differentiation bind to cell surface receptors which have tyrosine kinase activity, so-called receptor tyrosine kinases (RTKs).

The receptor tyrosine kinases (monomeric in the active form) are made up of an extracellular binding domain, a single membrane-spanning $\alpha-$ helix and a cytosolic domain with tyrosine kinase activity. On binding an extracellular ligand, the receptors dimerize and the kinase domain of one receptor molecule recognizes and phosphorylates tyrosine residues of the other monomeric unit (Scheme 1). The phosphorylated receptors are subsequently recognized by adaptor molecules. Of particular importance is the protein $G r b 2$ (growth factor receptor binding protein 2); this binds, with the help of a so-called SH2 (sarcoma homology 2) domain, to the peptide sequence of the receptor in which the phosphotyrosine is located. Grb2 also contains two SH3 domains that recognize proline-rich sequences in another adaptor protein, Sos (son of sevenless, named after a Drosophila mutant) (Scheme 1).

Scheme 1

Sos then interacts with the inactive, GDP-binding form of the protein Ras (from rat sarcoma) which is located in the membrane. Ras exchanges GDP for GTP following interaction with the Grb/Sos complex, which acts as a kind of "molecular glue", thus Grb/Sos functions as a guanine nucleotide exchange factor (GEF). This activates Ras which then acts as a molecular switch, diverting the signal arriving from the tyrosine kinase receptor by noncovalent protein-protein interactions to a cascade of protein phosphorylations and into the cell interior (Scheme 1). 

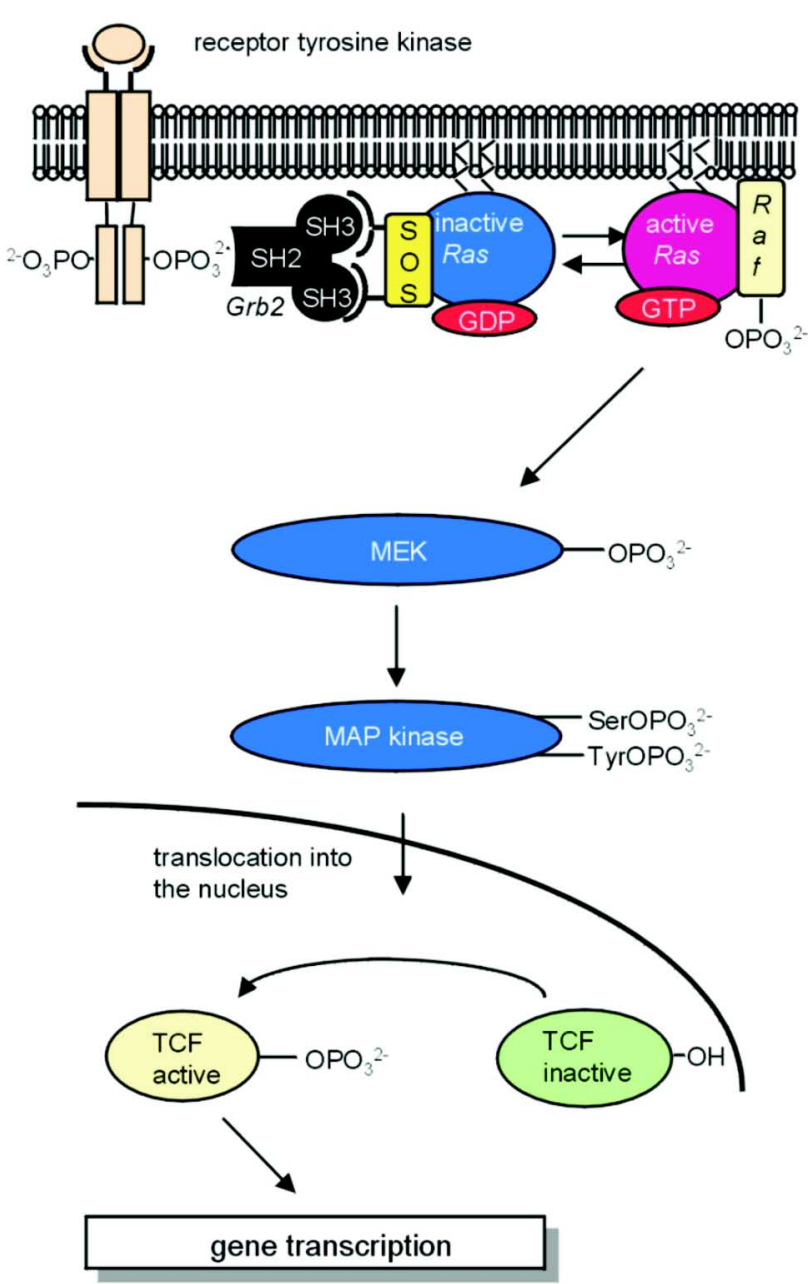

Scheme 1
The activated, GTP-binding form of Ras binds to the $N$-terminus of the serine/threonine kinase $R a f$ and thus localizes $R a f$ on the plasma membrane. With its $C$-terminus, Raf now binds the protein kinase MAP kinase kinase (from mitogen activated protein), also known as MEK (from MAP and ERK, extracellular signal regulated kinase), and phosphorylates it. This activates MEK which has tyrosine and serine/ threonine kinase activity and it phosphorylates the protein MAP kinase, which is a serine/threonine-specific kinase.

The activated MAP kinase now diffuses into the cell nucleus and phosphorylates transcription factors there, such as the ternary complex factor (TCF, also known as $E L K-1$ ) and the Jun protein, which are thereby activated and stimulate expression of the corresponding genes.

The Ras pathway is highly conserved in different species, ${ }^{[5,6-8]}$ such as yeast, worms, flies and mammals. Furthermore, it has recently been shown that in mammalian cells, there are at least three more signal transduction pathways, based on the same scheme as the Ras pathway, which conduct different extracellular signals to the cell nucleus. ${ }^{[1]}$ Other signal transduction cascades, for example via Janus kinases and STAT molecules ${ }^{[15,16]}$ or via the T-cell receptor, ${ }^{[17,18]}$ will not be discussed in this review.

\section{Inhibition of protein tyrosine kinases (PTKs)}

PTKs play an important role in cellular signal transduction and influence the correct course of many genetic programs, e.g. in the Ras signal cascade (see 2.1). Also half of all proto-oncogenes discovered so far code for proteins with PTK activity; ${ }^{[19]}$ thus, there is an intensive search underway for selective inhibitors of PTKs. ${ }^{[20]}$ Such substances would enable selective interruption of signal transduction cascades and the branching of various signal paths, in order to gain a better understanding of the molecular sequence of signal transmission; they could provide ways to treat diseases associated with abnormal PTK activity, such as cancer, psoriasis, restenosis or septic shock. ${ }^{[20 a]}$ Examples of natural substances with PTK-inhibiting activity are

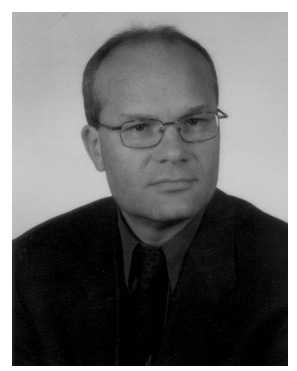

Herbert Waldmann, born in 1957, received his Dr. rer. nat. in 1985 (Universität Mainz, H. Kunz). After postdoctoral studies (1985-1986, Harvard University, George Whitesides) and habilitation (1991, Universität Mainz) he accepted a professorship at the Universität Bonn in 1991. In 1993 he moved to the Universität Karlsruhe where he now is Full Professor of Organic Chemistry. Herbert Waldmann has been the recipient of the Friedrich Weygand Award for the advancement of peptide chemistry and of the Carl Duisberg Award of the Gesellschaft Deutscher Chemiker.

His current research interests include bioorganic chemistry, in particular the synthesis and biological evaluation of peptide conjugates and natural products which are involved in biological signal transduction processes as well as biocatalysis, stereoselective synthesis, peptide-, carbohydrate and alkaloid chemistry and combinatorial chemistry.

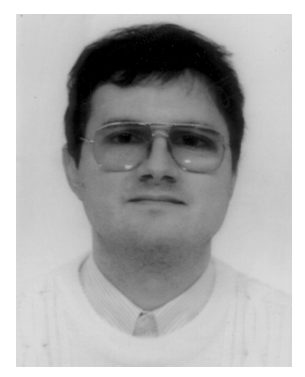

Thierry Schmittberger, born in 1969, studied chemistry at the University of Strasbourg. He joined there the research group of Professor Daniel Uguen and obtained his Ph.D. in 1996. In his thesis he concentrated on the synthesis of sterol side chains by using enzymatic techniques. In 1997 he joined the research group of Professor Herbert Waldmann, where he works on the synthesis of lipid-modified Ras peptides. 
radicicol $\mathbf{1},{ }^{[21]}$ lavendustin A $\mathbf{2},{ }^{[22]}$ and the tyrphostines $\mathbf{3},{ }^{[20 \mathrm{a}, \mathrm{b}, \mathrm{e}]}$ (Fig. $1)$.<smiles>O=C(/C=C\C=C/C[C@H]1Cc2c(Cl)c(O)cc(O)c2C(=O)O1)C[C@@H]1CO1</smiles>
radicicol 1<smiles>O=C(O)c1cc(N(Cc2ccccc2O)Cc2cc(O)ccc2O)ccc1O</smiles>

lavendustin A 2 $n(R O)$<smiles>[R2][Y]1cnc2ccccc2[Y]:1[H]</smiles>
tyrphostines 3<smiles>CCC/C=C\c1ccccc1/C=C/C(=O)N[C@@H](Cc1ccc(O)cc1)C(=O)N[C@@H](Cc1ccc(OC)c(O)c1Cl)C(=O)N[C@@H](Cc1ccccc1)C(=O)OC[C@H]1NC(=O)CNC1=O</smiles>

pepticinnamin E 4<smiles>CCC[C@H](NC(=O)CN1C(=O)[C@H](N(C)C[C@H](N)CS)N=C(c2ccccc2)c2ccccc21)C(C)=O</smiles>

5<smiles>CCC(C)[C@H](COC(Cc1ccccc1)C(=O)N[C@@H](CCCS(C)(=O)=O)C(=O)OC)NCC(N)CS</smiles>

6

\section{Figure 1}

Radicicol 1, a metabolite of the microparasite Monocillium nordinii has a variety of biological activities. In addition to its activity as an antifungal antibiotic ${ }^{[23]}$ and a tranquilizer, ${ }^{[24]}$ radicicol was particurlarly intensively examined for its selective and potent PTK-inhibitory activity. ${ }^{[25]}$ Since the natural substance is difficult to isolate, development of an efficient total synthesis (only one is published so $\mathrm{far}^{[26]}$ ) provides the opportunity to produce enough material for biological and medical studies. Particular challenges for the synthesis were the construction of the 14-member macrolactone and of the conjugate dienone epoxide with a $\mathrm{E}$ and $\mathrm{Z}$ double bond.

Lavendustin A 2 selectively inhibits the protein tyrosine kinase activity of the EGF receptor, whilst it only has a weak effect on the activity of the cAMP-dependent kinase (PKA) or PKC. ${ }^{[27]}$ Lavendustin A, and analogues, could be synthesized using combinatorial chemistry. The basic skeleton can be assembled from three aromatic units by simple and effective reactions and it can be bound to the solid phase via phenolic functions or via the carboxylic acid. ${ }^{[28]}$

Tyrphostines 3 are used as inhibitors of tumor growth, ${ }^{[29]}$ and of synthetic PTKs. They are also well investigated as initiators of cell differentiation. ${ }^{[30]}$ Numerous tyrphostines have been prepared and used for biological studies. This class of compounds belongs to the most often and successfully used chemical reagents for biological studies. [20b]

\section{Inhibition of the Ras protein farnesyl transferase (PFTase)}

Ras proteins function as central switches for signals emitted by growth factors that direct cell growth, cell differentiation and other genetic programs. ${ }^{[31]}$ The Ras proteins must be associated with the membrane to perform this function. They are anchored in the membrane by co- and post-translational modification of the $C$-terminus of the polypeptide with lipid residues which bind the protein to membranes. ${ }^{[32]}$ To this end, the cysteine of the $C$-terminal CAAX sequence ( $\mathrm{C}$ is cysteine, $\mathrm{A}$ is generally an aliphatic amino acid, $\mathrm{X}$ is methionine, serine, alanine or glutamine) is first enzymatically farnesylated during biosynthesis of a precursor protein, then the AAX part is cleaved off by a specific protease and finally the free terminal cysteine is converted to the methyl ester. In addition, in $\mathrm{H}-$ and $\mathrm{N}-\mathrm{Ras}$, a further lipid modification of cysteine occurs by formation of palmitoyl thioesters in the immediate vicinity of the CAAX motif. It has been shown that the farnesylation is essential for the transforming activity of mutated Ras proteins. ${ }^{[33]}$ Inhibition of this lipid modification opens up various possibilities for study of signal transduction processes and for development of alternative medical-chemical strategies.

In screening tests, natural substances with PFT-inhibiting activity, such as pepticinnamin E 4 (Fig. 1), ${ }^{[34]}$ were found.

A total synthesis ${ }^{[35]}$ of pepticinnamin $\mathrm{E} \mathbf{4}$ was of a considerable interest to determine the absolute configuration of the unusual central amino acid. Also due to the modular construction of pepticinnamin E, the development of a synthesis of this PFT inhibitor permits various derivatizations and the combinatorial synthesis of analogues with modified biological activity.

Substances that act in competition to the peptide, in particular to the CAAX motif, should have particularly advantageous selectivity of inhibition toward other enzymes since geranylgeranyltransferases prefer different sequence motifs (CAAL, where $\mathrm{L}$ is leucine) to the PFTases. ${ }^{[33]}$ Benzodiazepines 5 (Fig. 1) are CAAX peptidomimetics with a central unit that imitates a $\beta$-turn. In addition, they bring the $\mathrm{NH}_{2}$ terminus of the cysteine analogue and the $\mathrm{COOH}$ terminus of the methionine in spatial proximity; these can then complex a $\mathrm{Zn}^{2+}$ ion which is essential for activity of the PFTase and binding of the peptide substrate.

Peptides analogues, such as 6 (Fig. 1) ${ }^{[36]}$ (analogues of CAAX peptides in which peptide amide bonds are replaced by ether and amine groups) are also effective PFT-inhibitors.

Such compounds have not only shown pronounced in vitro activity but they also gave very promising results in in vivo investigations. Thus, PFT inhibitors are actively being investigated as new drugs for the treatment of cancer.

\section{Peptide conjugates as tools for study of biological signal transduction}

The proteins involved in transduction of signals from the plasma membrane into the cell nucleus often have additional covalently linked 
structural units which are absolutely necessary for fulfillment of their biological function (Fig. 2). For example, the cell surface receptors for growth factors (see Scheme 1), and the ligands recognized by them, are often glycoproteins in which serine, threonine and asparagine units are linked to oligosaccharides (see 7, Fig. 2). The signal-transmitting proteins located in the membrane, such as the Ras protein, are lipidmodified at cysteine and glycine residues (see 8). In many cases, the signals are passed on by phosphorylating proteins to be switched on at serine, threonine (see 9) and tyrosine residues; DNA, which is often the target of the signal cascade, exists as a nucleoprotein in which serine, threonine or tyrosine are linked as phosphoric acid esters to the nucleic acid chain (see 10).
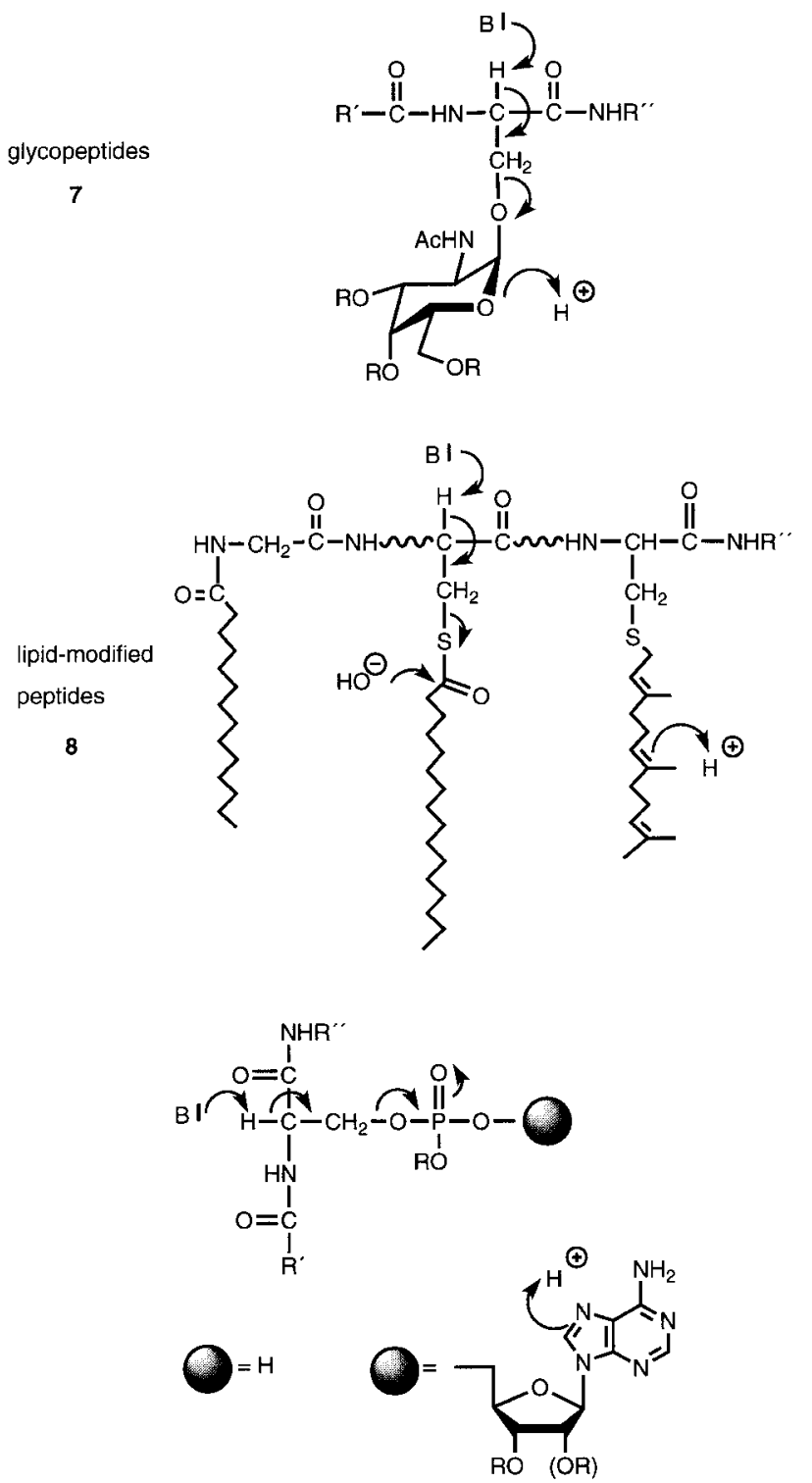

phosphopeptides 9

nucleopeptides 10

Figure 2

For the study of biological phenomena in which such protein conjugates are involved, peptides which embody the characteristic linkage region between the peptide backbone and the side chain modifications may serve as efficient reagents. ${ }^{[3]}$

Synthesis of such peptide conjugates is hindered by their multifunctionality (the use of orthogonally stable protecting groups ${ }^{[37]}$ is necessary), and by their acid- and base sensitivity. Thus at $\mathrm{pH}>9$, the side chain functions are cleaved from the glycosides $\mathbf{7}$, the lipidmodified peptides $\mathbf{8}$ and the phospho- and nucleopeptides $\mathbf{9}$ and $\mathbf{1 0}$ in a $\beta$-elimination; the thioester in $\mathbf{8}$ hydrolyzes spontaneously in aqueous solution at $\mathrm{pH}>7$. In acid, there is a danger of anomerization or even cleavage of the $N$ - and $O$-glycosidic bonds in $\mathbf{7}$ and $\mathbf{1 0}$ and the olefins of the farnesyl residue in $\mathbf{8}$ are easily attacked by acids. In the synthesis of the peptide conjugates of type 7-10, all reactions must take place under mild conditions.

The chemistry of the peptide conjugates has received much attention in the last two decades; this has led to development of high performance synthesis methods and use of modified peptides in biological studies.

\subsection{Lipid-modified peptides}

Signal transducing proteins that are located in the plasma membrane often carry covalently attached lipid residues. ${ }^{[38,39]}$ Thus, the $C$-termini of many G-protein-coupled receptors (GPCRs) are $S$-palmitoylated on

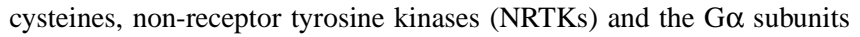
of heterotrimeric G proteins are $N$-myristoylated at $N$-terminal glycines and are often $S$-palmitoylated in the immediate vicinity as well. The $\gamma$ subunits of the $\mathrm{G}$ proteins contain an $S$-farnesylated or $S$ geranylgeranylated cysteine and the Ras proteins are $S$-farnesylated and S-palmitoylated (Fig. 3). The Ras proteins only fulfill their signal tranducing function if they are membrane bound, which is achieved by lipid modification.
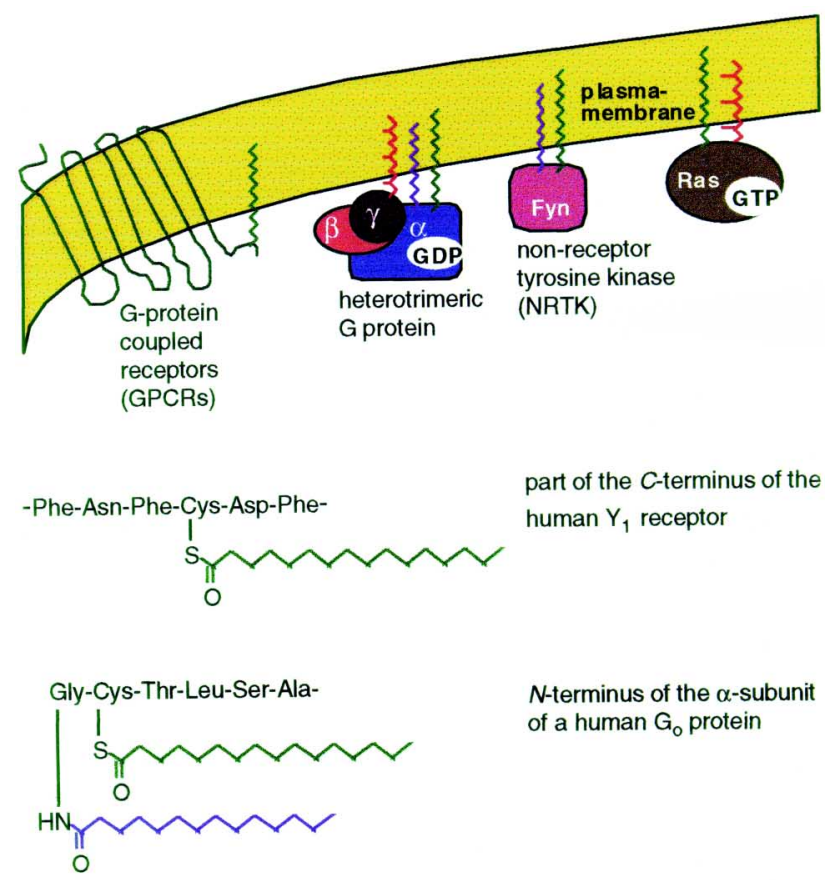

$N$-terminus of the $\alpha$-subunit of a human $G_{0}$ protein

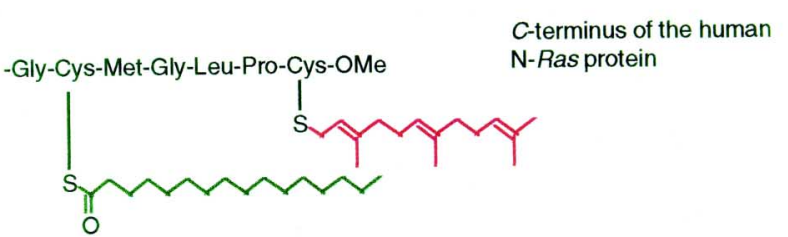

Figure 3

Enzymatic protective group techniques ${ }^{[37]}$ are particularly effective methods for synthesis of acid- and base-labile lipid-modified peptides. Thus, the choline ester was developed as an enzyme-labile carboxy protective group that can be released under very mild conditions using 
butyrylcholine esterase from horse serum; at the same time it ensures better solubility in the aqueous media due to its ionic character. ${ }^{[40]} \mathrm{An}$ example of its use is in the synthesis of the $S$-palmitoylated and $S$ farnesylated characteristic lipopeptide $\mathbf{1 6}$ of the human N-Ras protein (Scheme 2). The S-palmitoylated tripeptide choline ester $\mathbf{1 3}$ was obtained starting from the cysteine derivative $\mathbf{1 1}$ and in the most important step of the synthesis, $\mathbf{1 3}$ was selectively deprotected at the Cterminus without attack at the thioester. Extension of the peptide chain of the selectively demasked tripeptide $\mathbf{1 4}$ with the $S$-farnesylated tripeptide methyl ester $\mathbf{1 5}$ gave the target compound $\mathbf{1 6}$ with high yield.<smiles>CC(C)(C)[Se][Se]</smiles>
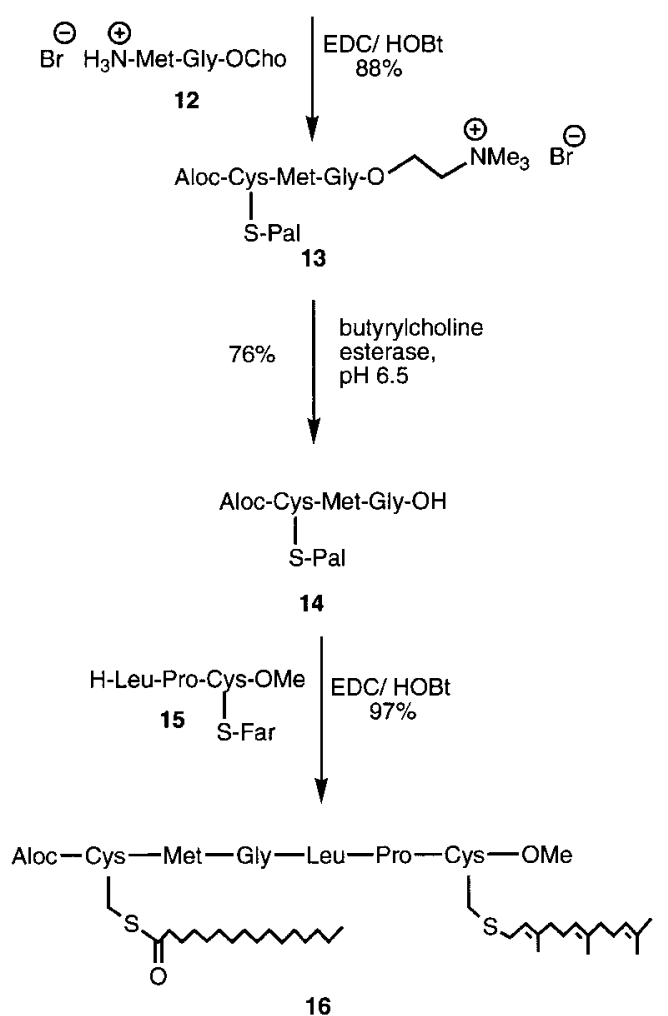

C-terminus of the human $\mathrm{N}$-Ras protein<smiles></smiles><smiles>CCN=C=NCCCN(C)C(=O)OC(C)(C)C</smiles>

Scheme 2

To enable synthesis of acid- and base-labile lipid-modified peptides by $N$-terminal extension of the peptide chain, it was necessary to develop the first enzyme-labile urethane protective group for the amino function of peptides (Scheme 3). ${ }^{[41]}$ A new strategy was developed in which the enzyme removes a urethane without direct attack on the urethane structure. The p-acetoxybenzyloxycarbonyl (AcOZ) group used for this purpose contains a functional group (an acetate) that the biocatalyst (an esterase or lipase) can recognize and which is bound via an enzymelabile bond (an ester) to a second functional group (a p-hydroxybenzyl urethane); following cleavage of the enzyme-labile bond, the urethane undergoes spontaneous fragmentation with release of the desired peptide conjugate (Scheme 3). Depending on the acyl residue selected (e.g. acetate or phenylacetate), enzymes with different selectivity (e.g. acetyl esterase or penicillin $\mathrm{G}$ acylase) can be used.
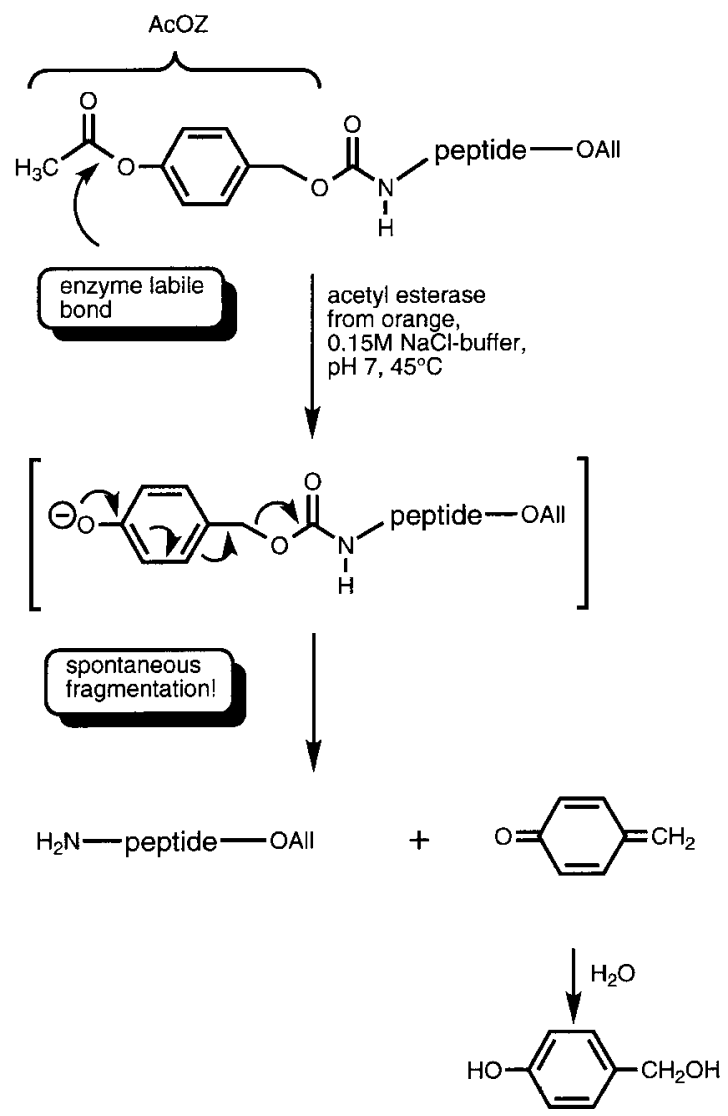

Scheme 3

Using the AcOZ urethane, the essential $C$-terminal lipid-modified heptapeptide ester $\mathbf{2 3}$ of the human N-Ras protein was constructed (Scheme 4). ${ }^{[1]}$ Deblocking of the urethane-protected farnesylated tripeptide methyl ester $\mathbf{1 7}$ by enzyme-initiated fragmentation of the $\mathrm{AcOZ}$ group delivered the selectively deprotected peptide. Successive extension of the peptide chain with an AcOZ dipeptide 18 and renewed lipase-mediated release of the urethane protective group gave the pentapeptide 20; this was condensed with the AcOZ-masked dipeptide $\mathbf{2 1}$ to give the fully protected lipid-modified heptapeptide 22. Enzymatic removal of the $N$-terminal urethane from $\mathbf{2 2}$ yielded the aminodeblocked Ras heptapeptide $\mathbf{2 3}$.

Such conjugates could also be assembled using classical methods. If only base-labile palmitic acid thioesters are present in the compound to be demasked, the acid-labile Boc group may be used; acid-labile $S$ farnesyl-cysteine-containing peptides can be deblocked at the $N$ terminus by cleavage of the Fmoc urethane. ${ }^{[42]}$ In addition to the enzymatic techniques, $\operatorname{Pd}(0)$-mediated release of allyl esters is an efficient method for synthesis of sensitive lipid-modified peptides. ${ }^{[43]}$ For example the $S$-palmitoylated and $S$-geranylgeranylated $C$-terminus 29 of the human R-Ras protein was built up using this method (Scheme 5 ). ${ }^{[4]}$ To this end, the $S$-palmitoylated cysteinyl tripeptide allyl ester $\mathbf{2 4}$ was synthesized from (BocGlyGlyCysOAll-S $)_{2}$ by reductive cleavage of the disulfide followed directly by $S$-acylation. $\mathrm{Pd}(0)$-mediated removal of allyl ester afforded the desired carboxylic acid 25, which was elongated by coupling with proline allyl ester 26. A further allyl ester cleavage delivered the $S$-palmitoylated tetrapeptide carboxylic acid $\mathbf{2 7}$ in high yield. Finally, the synthesis was completed by coupling 27 with 

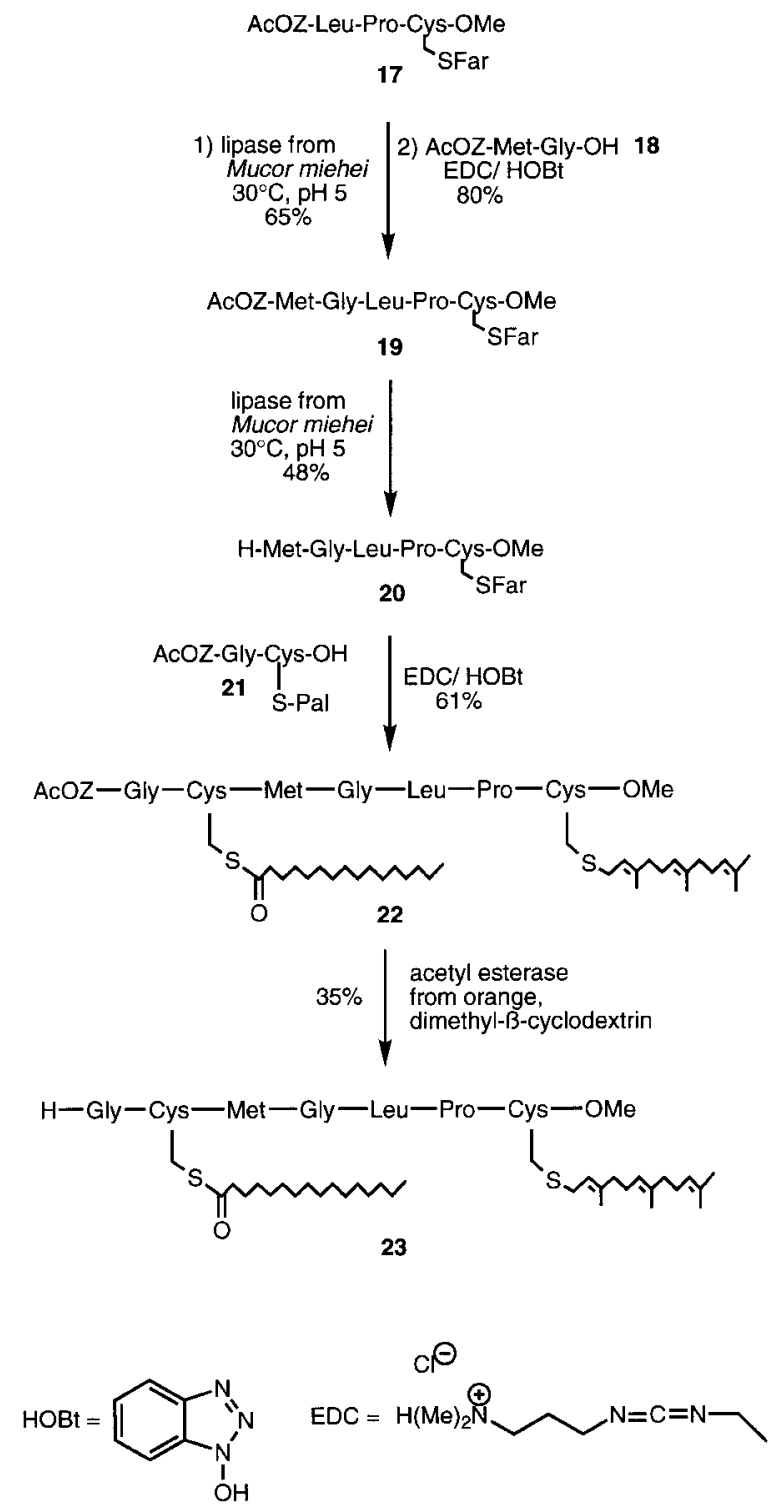

Scheme 4

$S$-geranylgeranylated cysteine methyl ester $\mathbf{2 8}$ to give the desired R-Ras peptide 29. All $\mathrm{Pd}(0)$-catalyzed allyl ester cleavage reactions proceeded without any undesired side reaction. In no case could a $\beta$-elimination or a nucleophilic attack on the activated thioesters be observed.

This protective group technique has demonstrated its potential in the development of a flexible building block system for synthesis of different lipid-modified $\mathrm{N}$-Ras peptides carrying additional fluorophoric groups (Fig. 4); due to the fluorophore properties, these conjugates can be followed in biological and biophysical experiments (see below).

Lipid-modified peptides have been used to obtain knowledge about the importance of the lipid residues in the function of lipid-modified proteins. In a series of biophysical investigations of the thermodynamics of insertion of lipid-modified model peptides in vesicles, functioning as model membranes, the contribution of the lipids to lipopeptide membrane affinity was determined. ${ }^{[45-47]}$ This showed that an $\mathrm{N}$ myristoyl or an $S$-farnesyl group alone cannot contribute enough hydrophobic character to maintain stable membrane insertion of peptides, and therefore also of proteins.

Biophysical model experiments on the kinetics of transfer of lipidmodified peptides from one model membrane to another ${ }^{[49,50]}$ showed
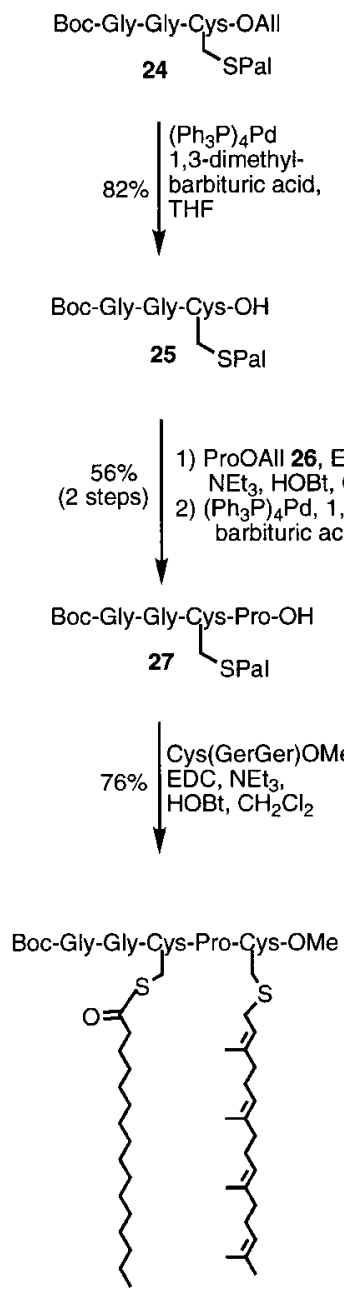

29

\section{Scheme 5}

that peptides and proteins that only carry a single lipid modification are rapidly inserted into the membrane (within seconds) yet they are also rapidly exchanged between two different membranes. The half time for transfer of a singly farnesylated or palmitoylated peptide is in the region of seconds. For peptides that are $N$-myristoylated and $S$-palmitoylated, or $S$-palmitoylated and $S$-farnesylated, the half times are in the region of hours to days. These values are significantly larger than the half time for exchange of $S$-acyl groups of membrane associated proteins in vivo (1-2 $\mathrm{h}$ or less).

These double lipid modifications give stable membrane binding in a biological context and on a biologically relevant timescale, and can be used as specific structural motifs to localize and anchor proteins in special subcellular membranes. In fact, the $N$-myristoyl $/ S$-palmitoyl motif is found in non-receptor tyrosine kinases and the $\alpha$-subunit of heterotrimeric G proteins, and $\mathrm{H}$-Ras and N-Ras are $S$-palmitoylated and $S$-farnesylated.

This hypothesis was tested by in vivo studies with fluorescently labeled $N$-myristoylated ${ }^{[51]}$ and $S$-farnesylated peptides. ${ }^{[43,50,51]}$ Peptides 30 and 31 (Fig. 4), which represent forms of the $N$-terminus of the human non-receptor tyrosine kinase $L c k$ and the C-terminus of human N-Ras protein with a single lipid modification, were $S$-palmitoylated in fibroblast cells. The palmitoylation was also observed for peptides in which the myristoyl residue had been exchanged for other fatty acids $\left(\mathrm{C}_{10}\right.$ to $\left.\mathrm{C}_{16}\right)$ or the farnesyl residue for other alkyl groups (n-undecyl, $\mathrm{n}$ octyl, trans-geranyl). 

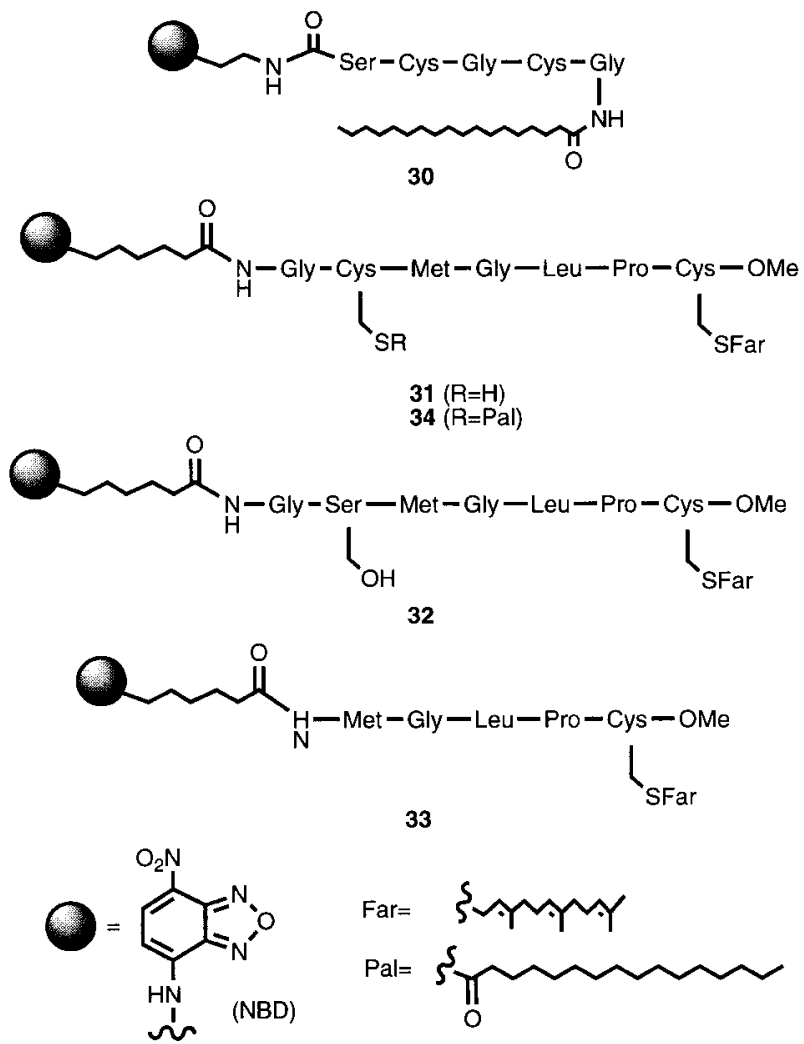

33

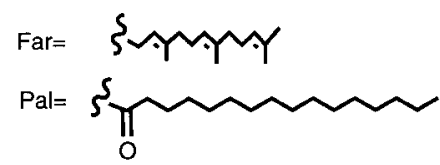

Figure 4

The site of palmitoylation and the intracellular distribution of peptides with a double lipid modification were determined using fluorescent microscopy techniques. This showed that the doubly lipid-modified peptides formed from $\mathbf{3 0}$ and $\mathbf{3 1}$ were concentrated in the plasma membrane of fibroblast cells; this took place under conditions $\left(15^{\circ} \mathrm{C}\right)$ which exclude intracellular transport, for example, by vesicles. For analogous serinyl peptides such as $\mathbf{3 2}$ which do not become acylated, such a selective distribution was not observed; the $S$-n-alkylated and geranylated analogues of 31 showed similar behavior. 30, 31 and 32 were introduced into cells by fusion of the fibroblast membrane with vesicles containing the fluorescently labeled peptide. The results were also confirmed by microinjection of $\mathbf{3 3}$ and $\mathbf{3 4}$ (Fig. 4) and subsequent examination by confocal laser fluorescence microscopy. ${ }^{[43]}$ This showed that the farnesylated, but no longer palmitoylatable, pentapeptide $\mathbf{3 3}$ was not selectively incorporated into a certain membrane, however the doubly lipid-modified $\mathbf{3 4}$ was selectively accumulated in the plasma membrane.

The doubly lipid-modified peptides (in contrast to singly modified) only exchange very slowly between different membranes when a second lipid residue is introduced (see above) and should therefore concentrate in the cell compartment in which the second lipid modification takes place. This led to the conclusion that $S$-palmitoylation of singly lipidated peptides (or proteins) takes place at the plasma membrane (Scheme 6).

The results of the biophysical and cell biology investigations support a model $^{[51]}$ for specific localization of proteins by myristoylation/ palmitoylation or farnesylation/palmitoylation. According to this model, the specific localization is not only determined by the lipid groups introduced in the course of the biosynthesis (in the case of Ras proteins, the farnesyl residue). Rather, the singly modified proteins can freely diffuse and insert in different membranes or desorb from these (Scheme 6 ). It is only on $S$-acylation in a certain membrane compartment that
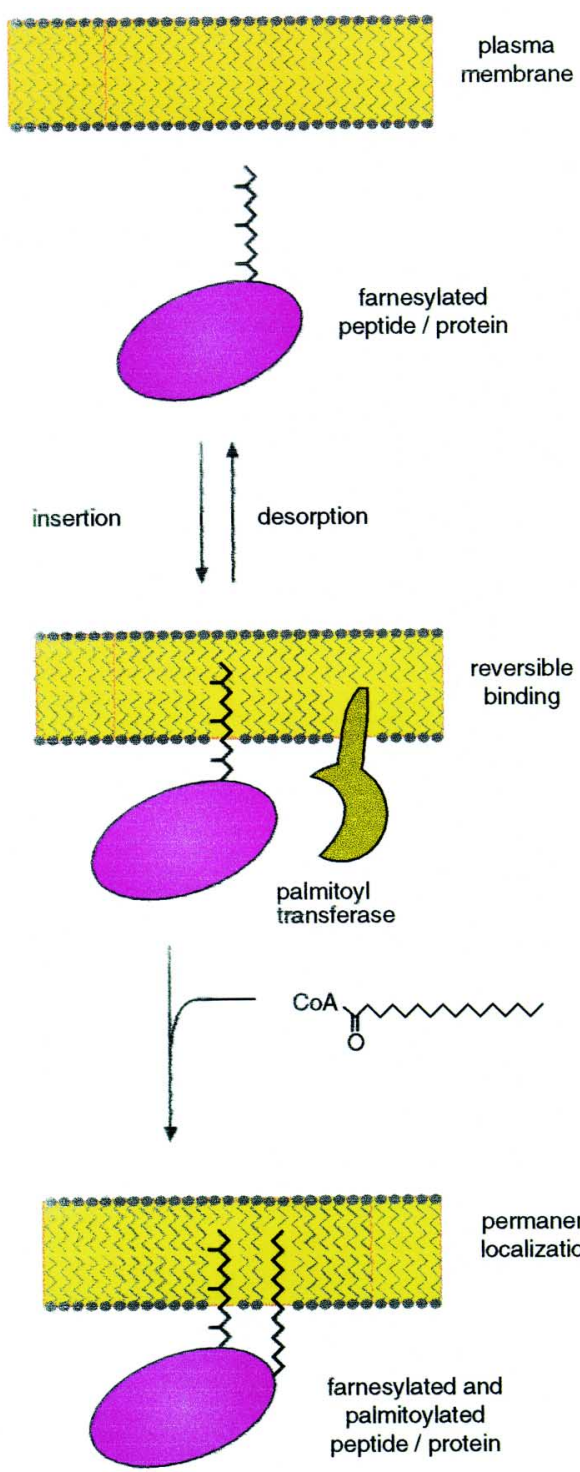

permanent localization

\section{Scheme 6}

they remain localized in that membrane. A membrane-bound protein $S$ acyltransferase that may be responsible for this modification was recently identified; it palmitoylates a farnesylated $\mathrm{N}$-Ras peptide and also the H-Ras protein. ${ }^{[52]}$ If the lipid-modified protein is no longer needed, or the signals transmitted by such proteins must be terminated (regulation of signal chains), the thioester can be cleaved again by a suitable hydrolase, initiating desorption of the protein from the membrane.

\subsection{Glycopeptides}

Many of the proteins localized on the extracellular side of the plasma membrane carry complex oligosaccharides. These glycoproteins are intensively involved in regulation of communication between cells; they control cell-cell interactions and form cell surface antigens. ${ }^{[53]}$ Taking this into consideration, it is particularly noteworthy that glycoproteins have also been identified as tumor-associated antigens, i.e. as antigens which appear on the surface of tumors but not on normal cells. In addition, many of the cell surface receptors that take up extracellular signals and conduct them through the plasma membrane into the cell interior are glycosylated. 
Characteristic glycopeptides could be useful tools for investigation of the biological functions of glycoproteins. In order to synthesize these peptide conjugates, both in solution ${ }^{[54 c]}$ and on solid phase (with PEGA resin, numerous glycopeptides were synthesized: for example see $\mathbf{3 5}$; Fig. 5), powerful techniques for reversible blocking of the amino, carboxy and alcohol groups have been developed as well as methods for protective release from polymeric carriers. ${ }^{[54-56]}$ Classical chemical synthesis of oligosaccharide units of glycoproteins has also reached a high level of efficiency. ${ }^{[57]}$

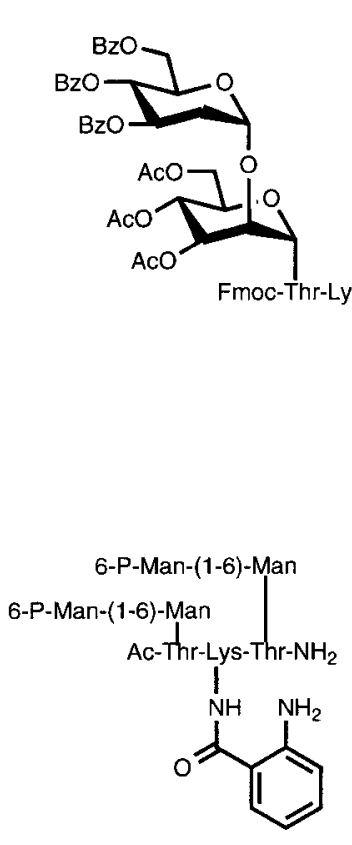

39

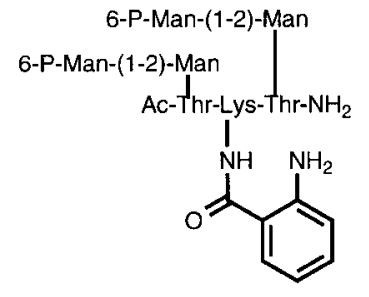

40

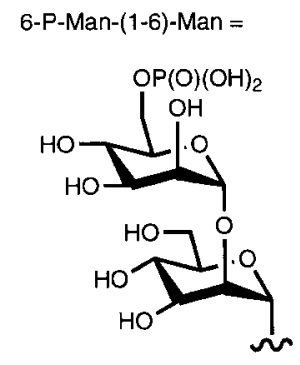

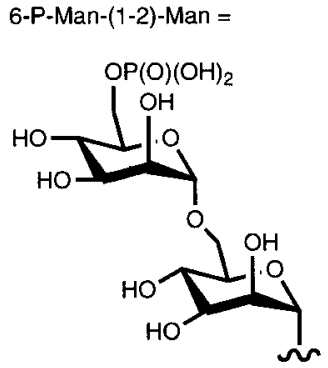

Figure 5

Enzymatic methods have opened up valuable alternatives for selective deblocking of glycopeptides and for synthesis of their oligosaccharide units. ${ }^{[58,59]}$ For example, selective and gentle enzymatic deblocking of $O$-glycopeptides was achieved by lipase-mediated hydrolysis of the heptyl ester protective group. The lipase from Mucor javanicus deblocks the $C$-terminus of the glycosylated amino acids and peptides 36,37 without unwanted attack on the $N$-terminal urethane and the carbohydrate protective groups (Scheme 7). Using this technique, the glycopeptide $\mathbf{3 8}$ was built up which represents a characteristic partial structure of a glycoprotein found on human brain cancer cells. ${ }^{[58]}$

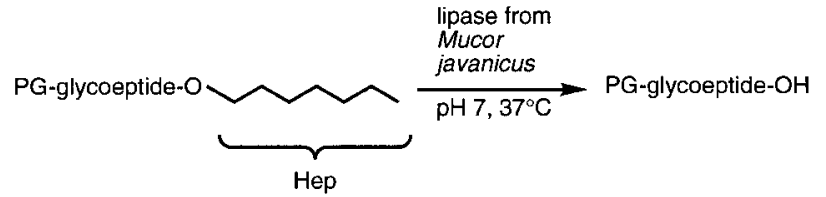

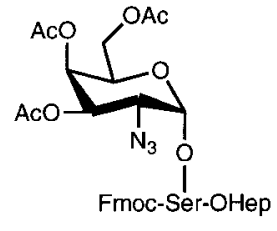

$3659 \%$

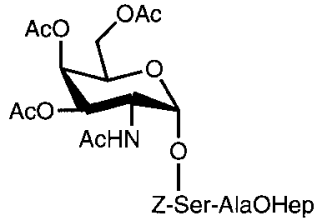

$3795 \%$

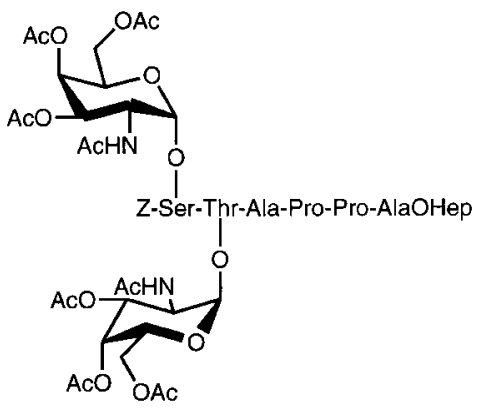

38

\section{Scheme 7}

Glycopeptides carrying the 6-O-phosphorylated mannose residue were used as reagents for study of the recognition of phosphorylated glycoproteins by the mannose-6-phosphate (Man-6-P) receptor. ${ }^{[60]}$ Lysosomal enzymes carry oligosaccharides with Man-6-P residues. Via these carbohydrates, they are recognized by Man-6-P receptors, then correctly processed and finally transported to the Golgi apparatus. Misregulation of these steps is involved in inflammatory processes in the central nervous system. Based on the suggestion that the receptor recognizes oligosaccharides with two Man-6-P residues diverse phosphorylated open-chain and cyclic glycopeptides such as 39-41 (Fig. 5) were synthesized. Examination of these compounds in a specially developed ELISA test revealed that high binding affinity was obtained if the ligands are bidentate and carry 6-O-phosphorylated $\alpha$-1,2-linked disaccharides; monosaccharides and phosphorylated $\alpha$-1,6-linked disaccharides are considerably less active. Three to five amino acids as spacer between the two saccharides are favorable.

\subsection{Phosphopeptides and glycophosphopeptides}

Protein kinase and phosphatase-mediated phosphorylation of proteins at serine, threonine and tyrosine residues is used in all organisms for regulation of many different intracellular processes, such as signal transmission from the plasma membrane to the cell nucleus and for direction of cell growth and division. ${ }^{[61]}$

The synthesis of phosphorylated serine and threonine peptides is impeded to a considerable extent by the extreme base lability of these peptide conjugates (see Fig. 2); protective groups which can be released under mild conditions are required. Peptides phosphorylated at tyrosine 
residues cannot lose the phosphate by $\beta$-elimination, however, and are much easier to synthesize for this reason. ${ }^{[62]}$

The base-labile Fmoc protective group cannot be used for synthesis of phosphopeptides without further modification, since serine and threonine phosphopeptides masked as phosphoric acid esters, unlike the more stable glycopeptides, lose the phosphate by $\beta$-elimination and formation of $\alpha, \beta$-dehydroalanyl peptides under the conditions for Fmoc cleavage. ${ }^{[63]}$ This disadvantage was overcome by introduction of the Fmoc-masked unit 42, which only carries a phosphoric acid diester (Fig. 6). ${ }^{[64,65]}$ Compound $\mathbf{4 2}$ is stable under treatment with piperidine to release the Fmoc group and is not apparently activated during the subsequent extension of the peptide chain. Using this building block, the phosphopeptide $\mathbf{4 3}$, which represents a phosphorylated partial sequence of the heat shock protein 27 , was synthesized on solid phase. ${ }^{[64]}$<smiles>CCCCOP(=O)(O)OCC(NC(=O)OCC1c2ccccc2-c2ccccc21)C(=O)O</smiles><smiles></smiles>

Figure 6

Enzymatic protective group techniques can also provide interesting and advantageous alternatives. ${ }^{[66]}$ For instance, by means of the lipasemediated removal of the heptyl ester protecting group (see Scheme 7) phosphopeptides could de selectively deprotected at the C-terminus without any undesired side reaction. Also, the enzymatic removal of the phenylacetamide from the $\mathrm{N}$-terminus of phosphopeptides opened up an alternative to classical-chemical methods.

Using enzymatic protective group techniques, also the first synthesis of a complex phosphoglycopeptide, which represents a characteristic section of the large $C$-terminal domain of the human RNA polymerase II, was achieved. ${ }^{[67]}$ In this synthesis (Scheme 8 ), both lipase-mediated cleavage of heptyl esters and also enzyme-initiated fragmentation of a urethane protective group (see 5.1) were employed.

On treating the fully protected glycosylated serine $\mathbf{4 4}$, which includes the enzyme-labile $\mathrm{PhAcOZ}$ group at the $N$-terminus with penicillin $\mathrm{G}$ acylase, only the phenylacetic acid ester was cleaved and the fragmentation of the resulting phenolate (same mechanism as shown in Scheme 3 for cleavage of the $\mathrm{AcOZ}$ group) led to release of the desired selectively deblocked amino acid $\mathbf{4 5}$. After linking to the glycodipeptide 46, also PhAcOZ-protected, to form the diglycotripeptide 47, penicillin $\mathrm{G}$ acylase re-released the $N$-terminus under very gentle conditions. A further cycle of chain extension gave the diglycopentapeptide 49, which is $N$-terminally deblocked and coupled with the allyl-masked serine derivative $\mathbf{5 0}$ to yield the molecule 51. Finally, successive release of all amino acid and carbohydrate protective groups gave the glycophosphopeptide $\mathbf{5 2}$.

Phosphorylated peptides have often been used as antigenic structural units for creation of monoclonal antibodies that recognize particular phosphoproteins. ${ }^{[68]}$ These antibodies serve, for example, as tools for immunodiagnosis of the tau protein in Alzheimer's disease.

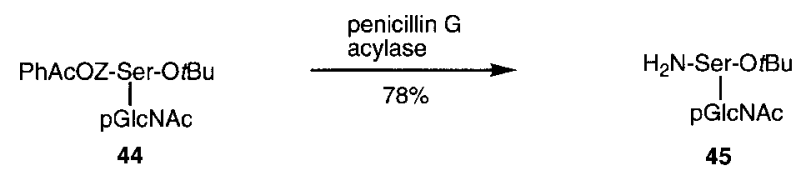

45

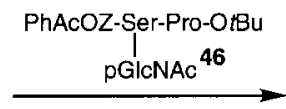
PhAcOZ-Ser-Pro-Ser-OtBu
pGlcNAcpGlcNAc

47
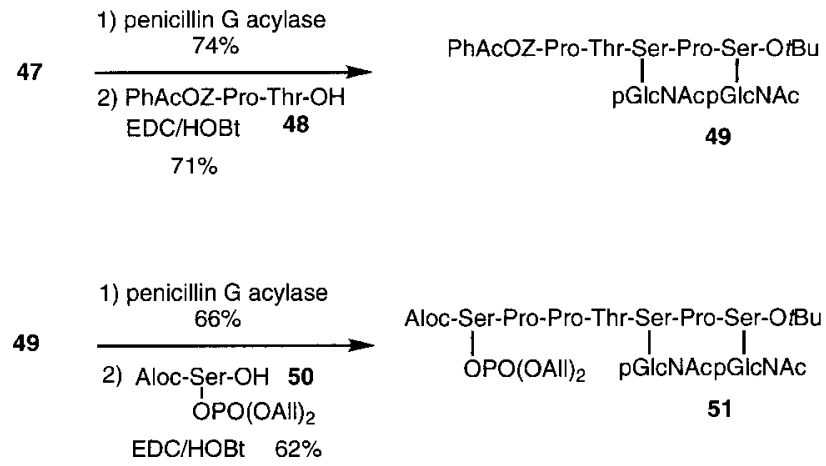

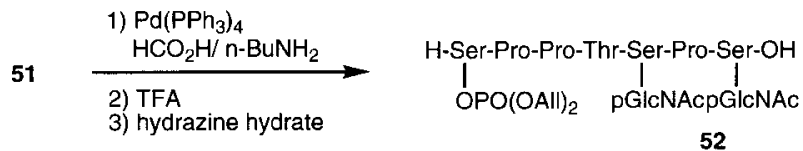

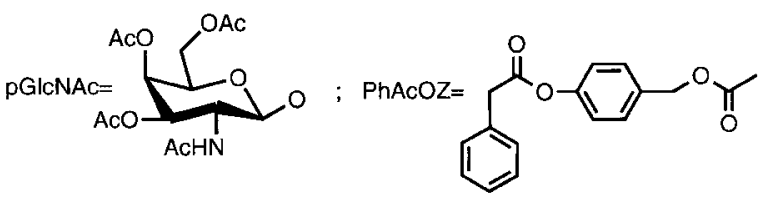

Scheme 8

\section{Conclusions and outlook}

The examples described in the previous sections of successful interlocking of organic chemical and biological work in investigation and influence of biological signal transduction clearly demonstrate the capabilities of interdisciplinary research in the field of bio-organic chemistry. For organic chemistry, this opens up a multitude of new spheres of activity, in which its capabilities can be used to the full extent and in which new, great and important challenges are presented which must be taken up: in mastering them, organic chemistry can rise to a key role. For biology, bio-organic research presents new alternative possibilities to obtain results faster, more directly and often with a greater degree of precision and clarity.

\section{Acknowledgement}

For generous support of our work, we would like to thank the Deutsche Forschungsgemeinschaft, the Bundesministerium für Bildung und Forschung, the Fonds der Chemischen Industrie, the European Union, the Alexander von Humboldt-Stiftung, the Krupp Stiftung, Bayer AG, 
BASF AG, Degussa AG, Boehringer Mannheim GmbH and Boehringer Ingelheim $\mathrm{KG}$.

\section{References and notes:}

[1] For a comment see: G. M. Whitesides, Angew. Chem. 1990, 102, 1247-1257; Angew. Chem. Int. Ed. Engl. 1990, 29, 1209-1219.

[2] This situation is also demonstrated in diverse new journals on subjects such as "Nature - Structural Biology", "Structure", etc.

[3] For a more comprehensive review see: K. Hinterding, D. AlonsoDiáz, H. Waldmann, Angew. Chem. 1998, in press.

[4] a) M. Rodbell, Angew. Chem. 1995, 107, 1549-1558; Angew. Chem. Int. Ed. Engl. 1995, 34, 1420-1428, b) A. G. Gilman, ibid. 1995, 107, 1533-1546 and 1995, 34, 1406-1419.

[5] For a comprehensive presentation, see: H. Lodish, D. Baltimore, J. Darnell, Molecular cell biology, 2nd edition, Scientific American Books, New York, 1990, Chap. 20.

[6] F. McCormick, Nature 1993, 363, 15-16.

[7] S. E. Egan, R. A. Weinberg, Nature 1993, 365, 781-783.

[8] M. S. Boguski, F. McCormick, Nature 1993, 366, 643-654.

[9] M. Spaargaren, J. R. Bischoff, F. McCormick, Gene Expression 1995, 4, 345-356.

[10] Intracellular Signal Transduction, Adv. in Pharmacology 36 (eds.: H. Hidaka, A. C. Nairin), Academic Press, San Diego, 1996.

[11] a) B. Stein, D. Anderson, Ann. Rep. Med. Chem. 1996, 31, 289298; b) C. E. Canman, M. B. Kastan, Nature 1996, 384, 213-214.

[12] M. L. Gishizky, Annu. Rep. Med. Chem. 1995, 30, 247-253.

[13] A. J. Bridges, Chemtracts - Organic Chemistry 1995, 8, 73-107.

[14] D. L. Cadena, G. N. Gill, FASEB J. 1992, 6, 2334-2337.

[15] P. Lamb, H. M. Seidel, R. B. Stein, J. Rosen, Annu. Rep. Med. Chem. 1996, 31, 269-278.

[16] J. E. Darnell Jr., I. M. Kerr, G. R. Stark, Science 1994, 264, 14151421.

[17] J. Kunz, M. N. Hall, Trends Biochem. Sci 1993, 18, 334-338.

[18] M. N. Pruschy, D. M. Spencer, T. M. Kapoor, H. Miyake, G. R. Crabtree, S. L. Schreiber, Chem. Biol. 1994, 1, 163-172.

[19] T. Hunter, Cell 1991, 64, 249-270.

[20] Reviews: a) A. Levitzki, FASEB J. 1992, 6, 3275-3282; b) A. Levitzki, A. Gazit, Science 1995, 267, 1782-1788; c) T. R. Burke Jr., Stem Cells 1994, 12, 1-6; d) T. R. Burke Jr., Drugs of the Future 1992, 17, 119-131; e) D. W. Fry, Annu. Rep. Med. Chem. 1996, 31, 151-160.

[21] H. J. Kwon, M. Yoshida, Y. Fukui, S. Hoeinouchi, T. Beppu, Cancer Res. 1992, 52, 6926-6930.

[22] T. Onoda, H. Iinuma, Y. Sasaki, M. Hamada, K. Isschiki, H. Naganawa, T. Takeuchi, K. Tatsuta, K. Umezawa, J. Nat. Prod. 1989, 52, 1252-1257.

[23] P. Delmotte, J. Delmotte-Paquee, Nature 1953, 171, 344-347.

[24] F. McCapra, A. I. Scott, P. Delmotte, J. Delmotte-Paquee, Tetrahedron Lett. 1964, 15, 869-875.

[25] H. J. kwon, M. Yoshida, Y. Fukui, S. Hoeinouchi, T. Beppu, Cancer Res. 1992, 52, 6926-6930.

[26] M. Lampilus, R. Lett, Tetrahedron Lett. 1992, 33, 773-776 and 777-780.

[27] C.-Y. J. Hsu, P. E. Persons, A. P. Spada, R. A. Bednar, A. Levitzki, A. Zilberstsein, J. Biol. Chem. 1991, 266, 31, 21105-21112.
[28] J. Green, J. Org. Chem. 1995, 60, 4287-4290; see also: R. Devraj, M. Cushman, ibid. 1996, 61, 9368-9373.

[29] See for example, T. Yoneda, R. M. Lyall, M. M. Alsina, P. E. Persons, A. P. Spada, A. Levitzki, A. Zilberstein, G. R. Mundy, Cancer Res. 1991, 51, 4430-4435.

[30] M. Anafi, A. Gazit, C. Gilon, Y. Benneriah, A. Levitzki, FEBS Lett. 1993, 330, 260-264.

[31] M. Barbacid, Annu. Rev. Biochem. 1987, 56, 779-827.

[32] J. F. Hancock, A. I. Magee, J. E. Childs, C. J. Marshall, Cell 1989, $57,1167-1177$.

[33] J. F. Hancock, H. Paterson, C. J. Marshall, Cell 1990, 63, 133-139.

[34] K. Shiomi, H. Yang, J. Inokoshi, D. Van der Pyl, A. Nakagawa, H. Takeshima, S. Omura, J. Antibiot. 1993, 46, 229-234.

[35] K. Hinterding, P. Hagenbuch, J. Retey, H. Waldmann, Angew. Chem. 1998, in press.

[36] N. E. Kohl, F. R. Wilson, S. D. Mosser, E. Guiliani, S. J. DeSolms, M. W. Conner, N. J. Anthony, W. J. Holtz, R. P. Gomez, T.-J. Lee, R. L. Smith, S. L. Graham, G. D. Hartman, J. B. Gibbs, A. Oliff, Proc. Natl. Acad. Sci. USA 1994, 91, 9141-9145.

[37] a) M. Schelhaas, H. Waldmann, Angew. Chem. 1996, 108, 21922219; Angew. Chem. Int. Ed. Engl. 1996, 35, 2056-2083; b) H. Waldmann, D. Sebastian, Chem. Rev. 1994, 94, 911-937; c) T. Kappes, H. Waldmann, Liebigs Ann. Recueil 1997, 803-813.

[38] P. J. Casey, Science 1995, 268, 221-225.

[39] G. Milligan, M. Parenti, A. I. Magee, Trends Biochem. Sci 1995, 20, 181-186.

[40] M. Schelhaas, S. Glomsda, M. Hänsler, H.-D. Jakubke, H. Waldmann, Angew. Chem. 1996, 108, 82-85; Angew. Chem. Int. Ed. Engl. 1996, 35, 106-109.

[41] H. Waldmann, E. Nägele, Angew. Chem. 1995, 107, 2425-2428; Angew. Chem. Int. Ed. Engl. 1995, 34, 2259-2262.

[42] P. Stöber, M. Schelhaas, E. Nägele, P. Hagenbuch, J. Rétey, H. Waldmann, Bioorg. Med. Chem. 1997, 5, 75-83.

[43] H. Waldmann, M. Schelhaas, E. Nägele, J. Kuhlmann, A. Wittinghofer, H. Schroeder, J. R. Silvius, Angew. Chem. 1997, 109, 2334-2337; Angew. Chem. Int. Ed. Engl. 1997, 36, 22382241.

[44] T. Schmittberger, A. Cotté, H. Waldmann, J. Chem. Soc. Chem. Commun., 1998, in press.

[45] S. Shahinian, J. Silvius, Biochemistry 1995, 34, 3813-3822.

[46] J. R. Silvius, F. l'Heureux, Biochemistry 1994, 33, 3014-3022.

[47] R. M. Peitzsch, S. McLaughlin, Biochemistry 1993, 32, 1043610443.

[48] C. A. Buser, C. T. Sigal, M. D. Resh, S. McLaughlin, Biochemistry 1994, 33, 13093-13101.

[49] S. Shahinian, J. Silvius, Biochemistry 1995, 34, 3813-3822.

[50] H. Schröder, R. Leventis, S. Rex, M. Schelhaas, E. Nägele, H. Waldmann, J. R. Silvius, Biochemistry 1997, 36, 13102.

[51] H. Schroeder, R. Leventis, S. Shahinian, P. A. Walton, J. R. Silvius, J. Cell Biol. 1996, 134, 647-660.

[52] L. Liu, T. Dudler, M. H. Gelb, J. Biol. Chem. 1996, 271, 326923276.

[53] a) A. Varki, Glycobiology 1993, 3, 97-130; b) L. A. Lasky, Science 1992, 258, 964-969; c) S. Hakomori, Adv. Cancer Res. 1989, 52, 257-331; d) T. Feizi, Nature 1985, 314, 53-57; e) J. C. Paulson in The Receptors, Vol. 2 (ed.: M. Conn), Academic Press, New York, 1985, p. 131-219. 
[54] a) W. Kosch, J. März, H. Kunz, React. Polym. 1994, 22, 181-194; b) O. Seitz, H. Kunz, J. Org. Chem. 1997,62, 813-826; c) H. Kunz, Angew. Chem. 1987, 99, 297-311.

[55] a) M. Christiansen, M. Meldal, H. Bock, J. Chem. Soc. Perkin Trans. 1 1993, 1453-1460; b) A. M. Jansson, K. J. Jensen, M. Meldal, J. Lomako, W. M. Lomako, C. E. Olsen, K. Bock. J. Chem. Soc. Perkin Trans. 1 1996, 1001-1006.

[56] a) M. Meldal, Tetrahedron Lett. 1992, 33, 3077-3080; b) M. Meldal, F.-I. Auzanneau, O. Hindsgaul, M. C. Palcic, J. Chem. Soc. Chem. Commun. 1994, 1849-1850.

[57] a) H. Paulsen, Angew. Chem. 1982, 94, 184-201; Angew. Chem. Int. Ed. Engl. 1982, 21, 155-172; b) R. R. Schmidt, ibid. 1986, 98 , 213-236 bzw. 1986, 25, 212-235; c) K. Toshima. K. Tasuda, Chem. Rev. 1993, 93, 1503-1531.

[58] a) P. Braun, H. Waldmann, H. Kunz, Bioorg. Med. Chem. 1993, 1, 197-207; b) P. Braun, H. Waldmann, H. Kunz, Synlett 1992, 3940.

[59] M. Schuster, P. Wang, J. C. Paulson, C.-H. Wong, J. Am. Chem. Soc. 1994, 116, 1135-1136.

[60] a) M. K. Christensen, M. Meldal, K. Bock, H. Cordes, S. Mouritsen, H. Elsner, J. Chem. Soc. Perkin Trans 1 1994, 12991310; b) H. Franzyk, M. K. Christensen, R. M. Jorgensen, M. Meldal, H. Cordes, S. Mouritsen, K. Bock, Bioorg. Med. Chem. 1997, 5, 21-40.

[61] a) Protein Phosphorylation (ed.: F. Marks), VCH, Weinheim 1996; b) T. Hunter, M. Karin, Cell 1992, 70, 375-387; c) E. G. Krebs, Angew. Chem. 1993, 105, 1173-1180; Angew. Chem. Int. Ed. Engl. 1993, 32, 1122-1129; d) E. H. Fischer, ibid. 1993, 105, 1181-1188 and 1993, 32, 1130-1137.
[62] J.W. Perich in Peptides and Protein Phosphorylation (ed. B. E. Kemp), CRC Press 1990, p. 289.

[63] a) A. Paquet, M. Johns, Int. J. Pept. Prot. Res. 1990, 36, 97-103; b) S. Ferrari, W. Bannwarth, S. J. Morley, N. F. Totty, G. Thomas, Proc. Natl. Acad. Sci. USA 1992, 89, 7282-7286.

[64] T. Vorherr, W. Bannwarth, Bioorg. Med. Chem. Lett. 1995, 5, 2661-2664.

[65] a) T. Wakamiya, K. Saruta, J. Yasuoka, S. Kusumoto, Chem. Lett. 1994, 1099-1102; b) T. Wakamiya, T. Nishida, R. Togashi, K. Saruta, J. Yasuoka, S. Kusumoto, Bull. Chem. Soc. Jpn. 1996, 69, 465-468; c) T. Wakamiya, R. Togashi, T. Nishida, K. Saruta, J. Yasuoka, S. Kusumoto, S. Aimoto, K. Y. Kumagaye, K. Nakajima, K. Nagata, Bioorg. Med. Chem. 1997, 5, 135-145.

[66] a) D. Sebastian, H. Waldmann, Tetrahedron Lett. 1997, 38, $2927-$ 2930; b) H. Waldmann, A. Heuser, S. Schulze, Tetrahedron Lett. 1996, 37, 8725-8728; c) D. Sebastian, A. Heuser, S. Schulze, Synthesis, 1997, 1098-1108.

[67] a) T. Pohl, H. Waldmann, Angew. Chem. 1996, 108, 1829-1832; Angew. Chem. Int. Ed. Engl. 1996, 35, 1720-1723; b) T. Pohl, H. Waldmann, J. Am. Chem. Soc. 1997, 119, 6702-6710.

[68] a) W.-K. Liu, W. T. Moore, R. T. Williams, F. L. Hall, S.-H. Yen, J. Neurosci. Res. 1993, 371-376; b) W.-K. Liu, S. H. Yen, J. Neurochem. 1996, 66, 1131-1139; c) P. Seubert, M. MawalDewan, R. Barbour, R. Jakes, M. Goedert, G. V. W. Johnson, J. M. Litersky, D. Schenk, I. Lieberburg, J. Q. Trojanowski, V. M.-Y. Lee, J. Biol. Chem. 1995, 270, 18917-18922; d) K. Ishiguro, K. Sato, M. Takamatsu, J. Park, T. Uchida, K. Imakori, Neurosci. Lett. 1995, 202, 81-84. 